Volume 1, Nomor 2, September 2019, pp 74-83. Copyright (C) 2019 JAFTA, Program Studi Magister Akuntansi, Fakultas Ekonomi, Universitas Kristen Maranatha. ISSN: 2654-4636| E-ISSN: 2656-758X https://journal.maranatha.edu/index.php/jafta

\title{
Design Management Accounting System for Village-Owned Enterprises
}

\author{
Oleh: \\ Rani Rahmawati \\ Salvana Anugerah Naftali \\ Nadifah Zukhriyah \\ Ignatius Oki Dewa Brata \\ Sendi Gunandar Arnan \\ Widyatama University \\ email: rani.rahmawati@widyatama.ac.id
}

\begin{abstract}
Indonesia were country that have many village cross the country. Government policy to rise economic in the villages through Village-Owned Enterprises were brilliant idea. But in the journey many things that need be done to make Village-Owned Enterprises can perform well. One of the most important point is made or design Accounting Information System. Whit this design Accounting Information System the researcher hope can help elevate the Village-Owned Enterprises organization function better than before. Design this system use three activities cycle that use in Accounting Information System. This paper describe the researcher activities in helping Village-Owned Enterprises in North Bandung city.
\end{abstract}

Keywords: Accounting, Information, System, Design, Village-Owned Enterprises

1.

\section{Introduction}

Indonesia is a country that has extraordinary

business potential. The country which is located in South Asia is a country which, according to the Head of the Central Statistics Agency Number 66 Year 2016 concerning the Code and Regional Statistics Work Area in 2016, has 82,030 villages.

This shows that the business potential that can be developed right in the village could have boosted the economy of the Indonesian people if it could be maximized. In accordance with government policy set forth in the Regulation of the Minister of Rural Development of Disadvantaged Regions, and Transmigration of the Republic of Indonesia Number 4 of 2015, that the business processes that exist within the village must be utilized properly through VILLAGE-OWNED ENTERPRISES.
The government has poured out village funds and Village fund pocket books to help the villages to allocate them professionally and on target.

Effective management must take into account not only the financial data, as they are presented in business annual financial statements, but also the way culture affects quantitative and qualitative organizational variables as well (Wisna, 2015; Inah, Tapang and Uket, 2014; Okpara, 2014; Denison, 1984, 1990, 1996, 2000). And Actually organizations today recognize the need to integrate the data associated with their functions into large, seamless data warehouses. This integration allows internal managers and possibly external parties to obtain the information needed for planning, decisionmaking and control, whether that information is for marketing, accounting or some other functional area in the organization (Bagranoff, Simkin and 
Norman, 2010). That's why Accounting Information System are Important

Accounting information system is a collection (integration) of sub-systems, both physical and non-physical, that are interrelated and work together in harmony with each other to process transaction or data related to financial issues into financial information (Azhar, 2008), an AIS is a structure that a company uses to collect, store, manage, process, retrieve and report its financial data so that it can be used by managers, accountants, consultants, investors and other stakeholders (Dagiliene L and Šutiene K., 2019), if we do have good Accounting Information System so the next step we can go to Managing Accounting System (MAS).

MAS service quality is important because it may lead to increased use of such services, higher levels of user satisfaction, and more effective decision making. Successful service provision will likely elevate the status of the accounting discipline in organizations, and lead to increased resource allocations. The issue of service quality is well researched in a number of disciplines, with hundreds of articles published across numerous organizational and service settings, including health care (Ward et al., 2005)

\section{Literature Review \\ Village}

What are village, accordance with government policy set forth in the Regulation of the Minister of Rural Development of Disadvantaged Regions, and Transmigration of the Republic of Indonesia Number 4 of 2015 that :

"Village is a modern village and a customary village or what is referred to by another name, hereinafter referred to as Village, is a legal community unit that has the authority to manage and administer government affairs, the interests of the local community based on community initiatives, original rights, and / or traditional rights recognized and respected in the government system of the Unitary Republic of Indonesia."

\section{Village-Owned Enterprises}

Accordance with government policy set forth in the Regulation of the Minister of Rural Development of Disadvantaged Regions, and Transmigration of the Republic of Indonesia Number 4 of 2015 that :

"Village-Owned Enterprises, hereinafter referred to as Village-Owned Enterprises, are business entities whose entire or most of their capital is owned by the Village through direct participation from village assets that are separated to manage assets, services, and other businesses for the maximum welfare of the village community."

\section{Organization and accounting information system}

Three factors that influence the design of an accounting information system: development in IT, business strategy and organizational culture (Marshall and Steinbart, 2017). An organizational culture perspective and perception of employees to create beliefs, values and expectations. It has been posited in the previous research (e.g. Marshall and Steinbart, 2017; Denison, 1984, 1990) that accounting information system is influenced by factors of corporate culture (corporate/organizational culture) which ultimately leads to corporate performance.

The low quality of accounting information systems in Ghana has been documented by the Ghana statistical service (GSS, 2017) and the Ghana Stock Exchange report (GSE, 2017) that reporting system of local government and private commercial entities on financial implementation tends to be inefficient in terms of both time and budget. Also, a number of listed firms failed to submit financial statements which incidentally is part of the listing requirements. Recent collapse of two major commercial banks in Ghana and its negative effects on various stakeholders 
has rekindled the debate about quality of financial information and reporting. The study therefore is timely to address the empirical gap in the relationship between organizational culture, accounting information system and corporate performance in the context of Ghana.

Hoque (2000) measured the use of cost information in terms of its appropriateness for monitoring the firm's organizational activities, such as the evaluation of managers' efficiency, the recognition of non-value-adding activities, the valuation of inventories, the analysis of customers' profitability, the design of production and sales strategy and so on.

More accurate information about production and support activities and product costs focuses management's attention on the products and processes with the most leverage in increasing profits. Also, better knowledge of product costs is a useful tool for making more effective decisions about product design, price setting, entering/ leaving markets, etc. and encouraging continual operating improvements (Cooper and Kaplan, 1988). According to Kaplan (1988), seriously distorted product costs can result to a losing competitive strategy by deemphasizing and overpricing products that are highly profitable and by expanding commitments to complex, unprofitable lines.

\section{COSO and COBIT frameworks}

COSO framework is designed to provide information security for banking organisations. It views internal controls as processes. COSO framework provides a design guiding organisations to implement a control system that would integrate all of the business processes. COSO has five control components: the Control Environment, Risk Assessment, Control Activities, Information and
Communication, and Monitoring (Eloff and Solms, 2000). The main objectives of these components are to assess and mange risks occurring when people perform their tasks, and evaluate the systems' performance over time through a monitoring activity. COBIT framework is for the overall IT controls of an organisation. It views the internal control as set of policies, procedures, practices and organisational structures (Doucet and Doucet, 2003). In contrast, COSO framework is designed to provide information security for the organisation. It views internal controls as processes (COSO, 1994). Both frameworks give importance to people related to the processes under each component. In COBIT framework, people are defined as staff skills, awareness and productivity to plan, organise, acquire, deliver, support and monitor information systems (Colbert and Bowen, 1996).

\section{Method}

Mitra Sejahtera Village Owned Enterprise is a Village Business Unit engaged in services such as Fresh Water Product (PAB), PPOB, ATK and Photocopy and Tourism Stalls and has a management structure in accordance with the decision of the village head and village regulations which have 1 coaching and 11 employees among executors consisting of : Directors, Secretary, and Treasuree and Units held by each Unit Head include: Head of Water Unit and Technicians, Head of PPOB Unit, Head of Photocopy Unit and ATK, Head of Tourism Stalls Unit and supervisor. The organizational structure implemented in Mitra Sejahtera Village Owned Enterprises is still quite functional. Because the Village Owned Business Unit was only established in 2016 and operated around 3 years ago. The organizational structure of Village Owned Enterprises Mitra Sejahtera is as follows : 
Coacher:

Operational:

Head of Water Unit:

Engineering I:

Engineering II:

Head of PPOB Unit:

Head of Foto Kopi \& ATK Unit:

Head of Tourism Unit:

Supervisor:
Ojat Kurnia, S.E

Director: Drs. Wawan Gunawan

Secretary: Ahmad Sobari

Treasurer: Asep Rahmat

Nana Sutarman

Ade Misri

Azis Alansyah

Asep Rahmat

Acep Setiawan

Ase Sobana

Head: Hilman Ruhiat

Secretary: Perawati

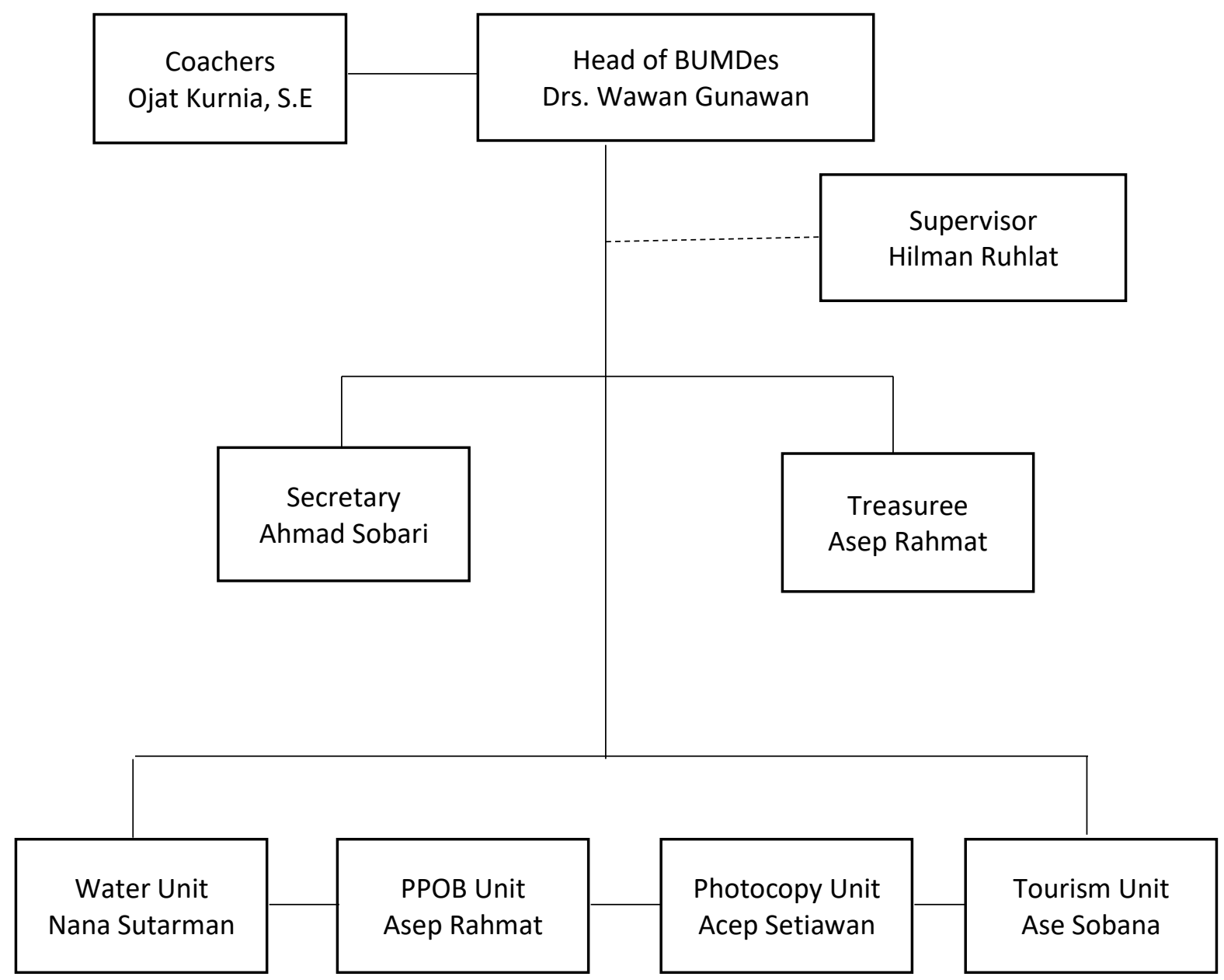

The method used by the author in this research is descriptive method, which is a method that describes or describes a particular problem related to how to collect data, compile, classify and compare with the theories discussed that can produce conclusions. While the descriptive method according to Sugiyono (2008) is as follows: "Descriptive research is research conducted to study the value of an independent variable, either one or more variables (independent) without making, or connecting with other variables."

The technique of receiving data needed as research material is as follows:

1. Field Study (Field Research), namely research conducted directly on the company submitted with the intention of obtaining the data and information needed by: 
JAFTA — Vol. 1 Nomor 2, September (2019)

a. Observation (observation), namely by finding the object of research and the results of research conducted by recording relevant to the problem being carried out. (Sugiyono, 2008)

b. Interview (Interview), namely by conducting question and answer with related parties to receive data and answer related to the problem being discussed. (Sugiyono, 2008)

2. Literature Study (Library Research), conducted by reading books, examining literature sources to obtain a theoretical basis and helping to prepare a final report. (Sugiyono, 2008)

\section{Findings}

\section{Reception and Revenue Cycle}

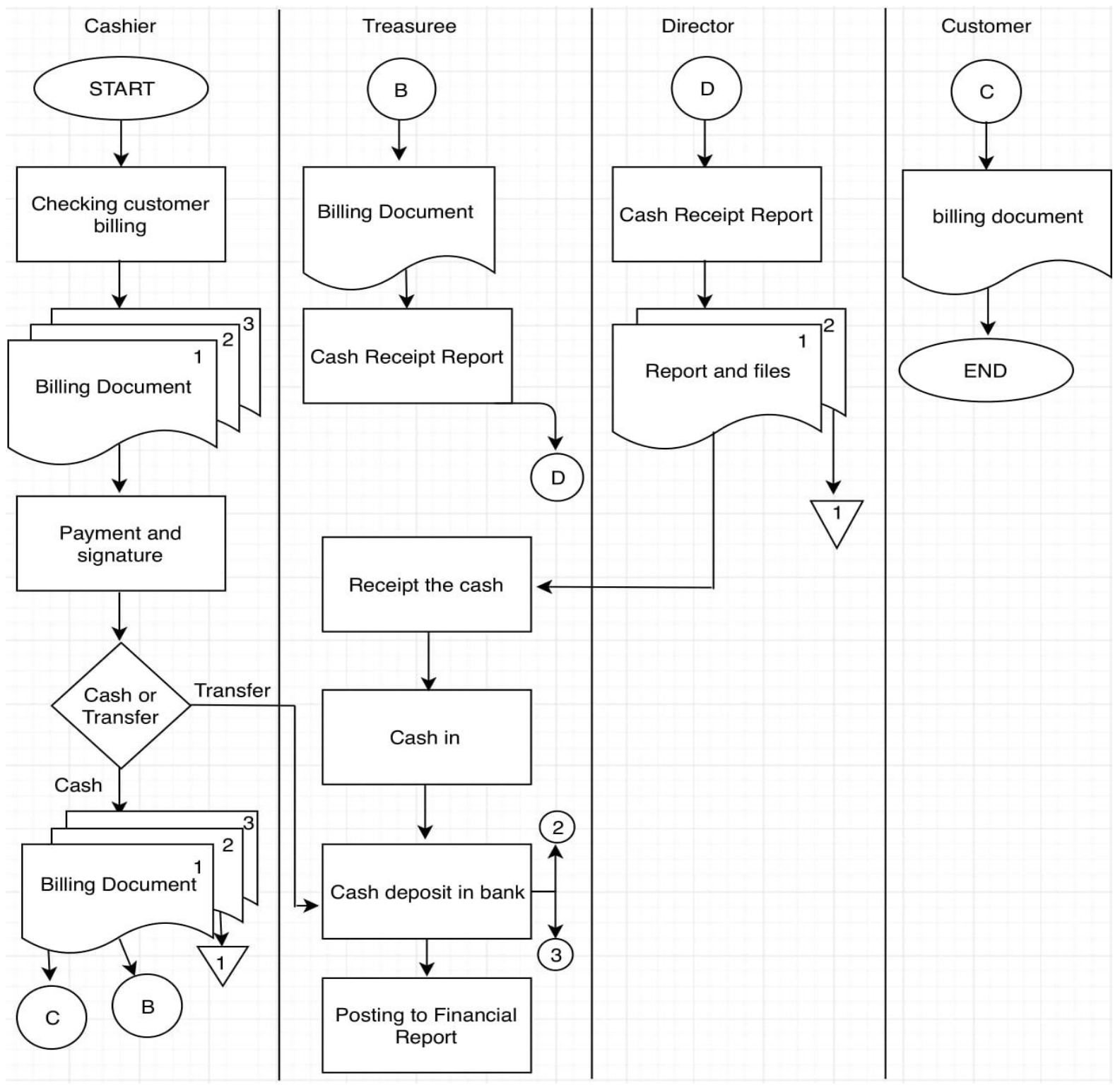

Receipt starts from the cashier, then checks the bill to the customer, then makes a document with 3 copies of which to collect the customer next to the payment and signature from the customer. Then issue a document in the form of copy 1 for recording and submitted to customer $\mathrm{C}$ copy 2 for recording treasurer B and copy 3 for archive1. For payments from customers can be through cash or 
JAFTA — Vol. 1 Nomor 2, September (2019)

transfer, when through a transfer, the one automatically enters the bank account. When paying through cash, the money along with a copy of $\mathrm{B}$ is handed over to the treasurer and then the treasurer recaps 2 copies of the document and makes a cash receipt report $D$. Then the cash receipt $\mathrm{D}$ is handed over to the director and then validated by passing the report and signature so that 2 documents are made. Copy 1 to treasurer, copy 2 of archives. From copy 1 to the treasurer, the treasurer recaps the report along with the money, then submits it to the bank (cash) and then posts it to the financial statements. When copy 1 is submitted to the customer, the cycle is complete.

\section{Expenditure Cycle}

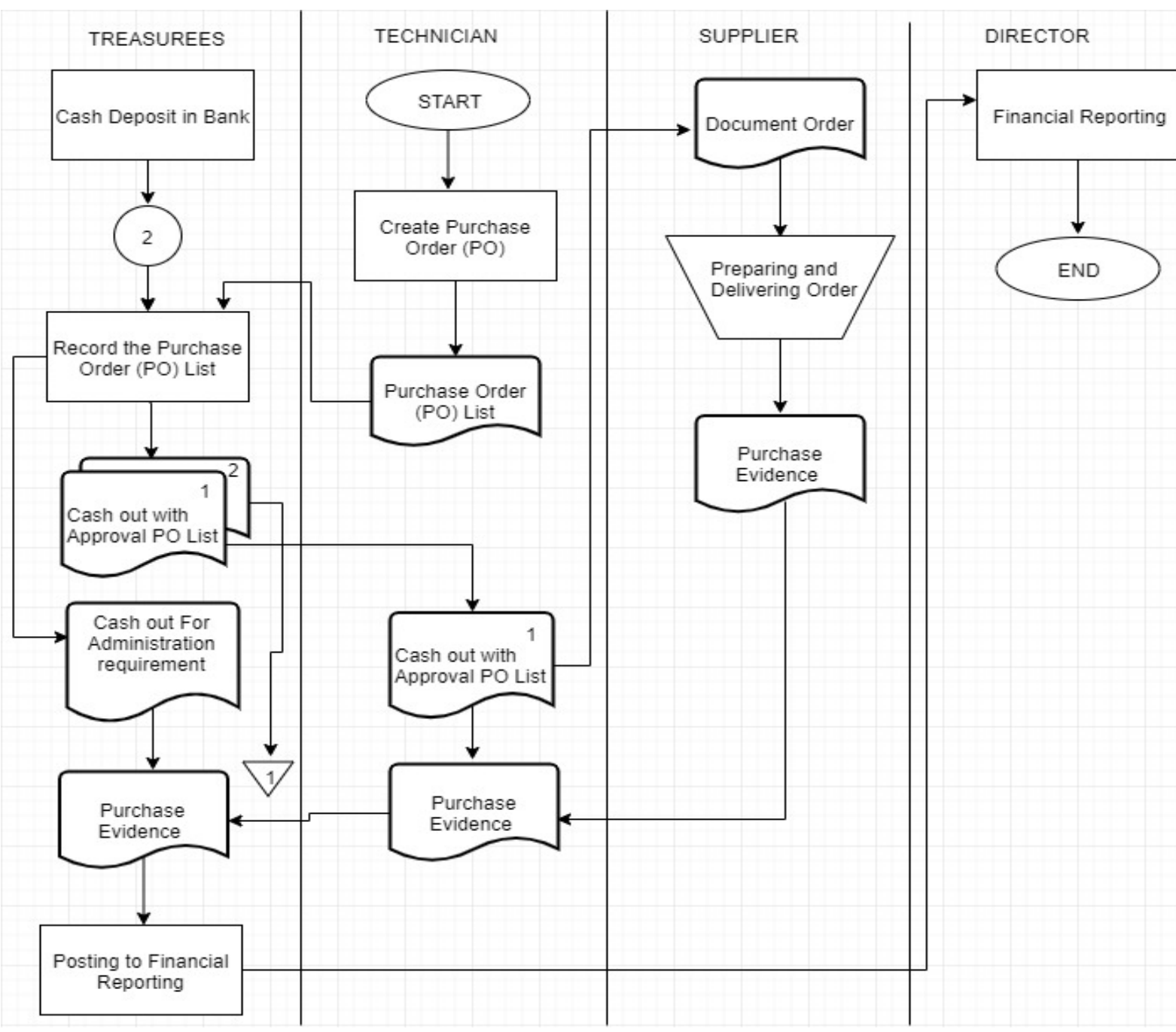

Expenditures start from the technician, then the technician makes a purchase order (PO), then the technician makes a PO list to be given to the treasurer, then the treasurer records the entire recapitulation of the $\mathrm{PO}$ list. After the $\mathrm{PO}$ is recorded, the treasurer approves and gives cash out to the technician, after the technician receives cash out from the treasurer then the technician buys the required goods as recorded to the supplier, then the supplier prepares and sends the goods that have been ordered by the technician. Then the supplier provides proof of receipt to the technician, then the technician also provides the receipt to the treasurer for posting to the financial statements. Then the treasurer reports to the director for validation and then the expenditure cycle is complete. 


\section{Managing Payroll Cycle}

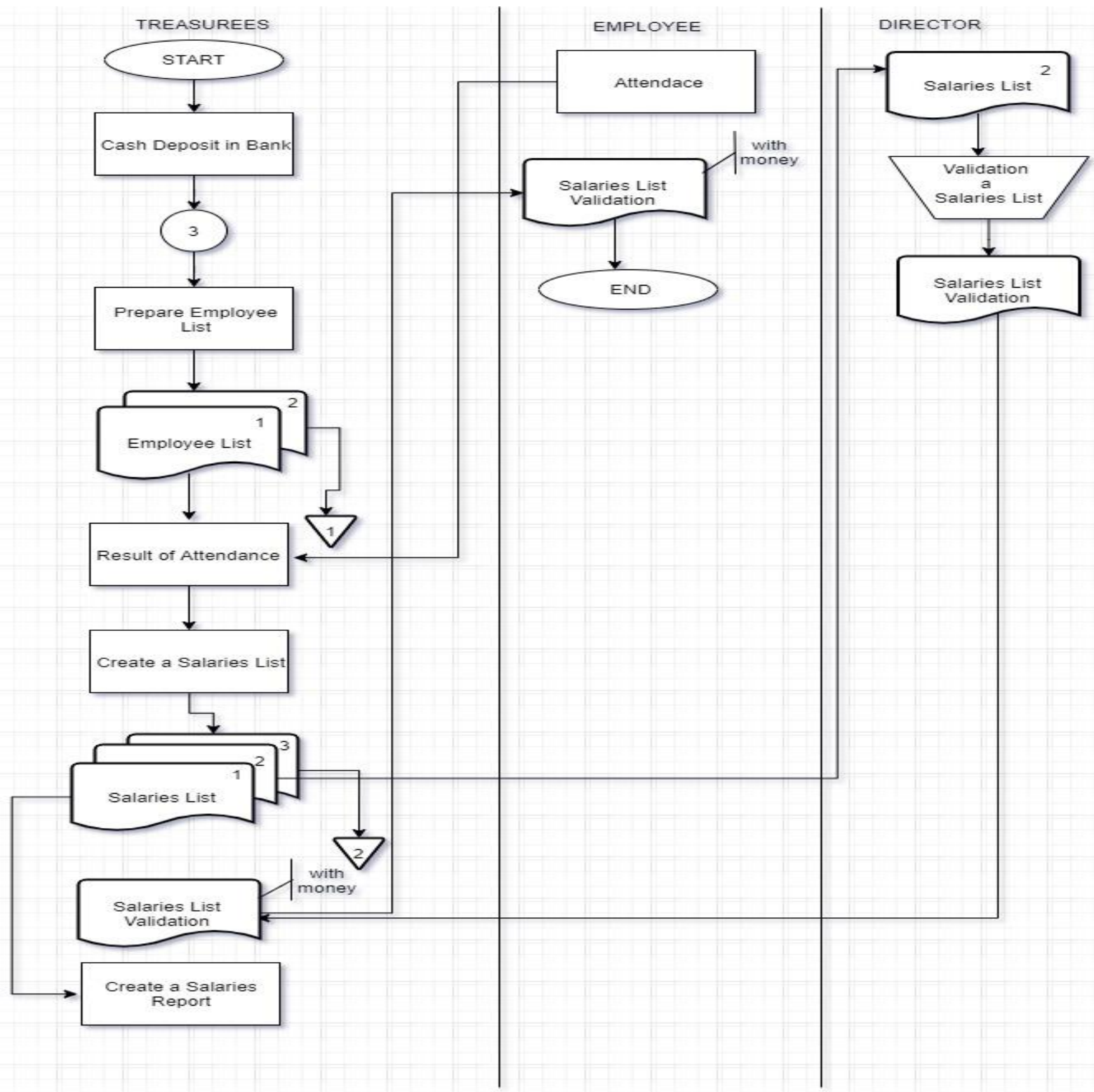

Payroll starts from the treasurer, cash at a special payroll bank. Then the treasurer prepares the employee list, then after preparing the employee list the treasurer employee list documents with two copies, 1 of which is for archives. When the employee list document has been made, then the results of attendance can be known, the treasurer makes a list of employee salaries, which then made a document with 3 copies of which to make a salary report then to be submitted to the director and the third copy for the archive. Furthermore, the employee prepares attendance for export by the treasurer, then the treasurer validates the payroll 80 and the money that will be given to the employee. when the employee has received validation, the cycle is complete.

\section{Discussion and Conclusion}

So the conclusions obtained from the above arrangement are the Making of a System for Village-Owned Enterprises with these three cycles starting from the cash receipts cycle, the cash renewal cycle, and the payroll cycle is very important for companies, especially village units namely the Village Owned Enterprises which are now being intensively and worked on by the 
JAFTA — Vol. 1 Nomor 2, September (2019)

regional government starting from the concern about the funding assistance for the village MIlik business entity to the control of an activity from the village MIlik business entity by the regional government. For this reason, the Village Owned Enterprise itself must have a system that is sufficiently capable and simple to regulate the operation of the village unit during the operation. So that we make these three cycles to help their operational performance to be structured and improve the performance and quality of the villageowned enterprises, especially the Mitra Sejahtera village-owned enterprises located in Ciburial Bandung so that they are more advanced and able to contribute to the government, especially in developing villages around. (Badan Pusat Statistik, 2016)

\section{REFERENCES}

Badan Pusat Statistik. (2016). Kode dan Wilayah Kerja Statistik Nomor 66 tahun 2016. In P. K. Statistik.

Peraturan Kepala Badan Pusat Statistik Nomor 66 Tahun 2016 tentang Kode dan Wilayah Kerja Statistik Tahun 2016.

Peraturan Menteri Desa Pembangunan Daerah Tertinggal, Dan Transmigrasi Republik Indonesia Nomor 4 Tahun 2015 Tentang Pendirian, Pengurusan Dan Pengelolaan, Dan Pembubaran Badan Usaha Milik Desa

Wisna, N. (2015), “Organizational culture and its impact on the quality of accounting information systems", Journal of Theoretical and Applied Information Technology, Vol. 82 No. 2, Harper and Row, New York.

Inah, E.U., Tapang, A.T. and Uket, E.E. (2014), "Organizational culture and financial reporting practices in Nigeria", Research
Journal of Finance and Accounting, Vol. 5 No. 13.

Okpara, J.O. (2014), "The effects of national culture on managers' attitudes toward business ethics: implications for organizational change", Journal of Accounting and Organizational Change, Vol. 10 No. 2, pp. 174-189.

Denison, D.R. (1984), "Bringing corporate culture to the bottom line", Organizational Dynamics, Vol. 13 No. 2, pp. 4-22.

Denison, D.R. (1990), Corporate Culture and Organizational Effectiveness, Wiley, New York, NY. Denison, D.R. (1996), "What is the difference between organizational culture and organizational climate? A native's point of view on a decade of paradigm wars", Academy of Management Review, Vol. 21 No. 3, pp. 619-654.

Denison, D.R. (2000), “Organizational culture: can it be a key lever for driving organizational change?", in Cooper, C.L., Cartwright, S. and Earley, P.C. (Eds), The International Handbook of Organizational Culture and Climate, John Wiley and Sons, Chichester, pp. 347-372.

Denison, D. and Mishra, A. (1989), “Organizational culture and organizational effectiveness: a theory and some preliminary empirical evidence", Academy of Management Proceedings, Vol. 1989 No. 1.

Bagranoff, N.A., Simkin, M.G. and Norman, C.S. (2010), Core Concept of Accounting Information Systems, 11th ed., John Wiley and Sons, Hoboken, NJ, pp. 7-8.

Azhar, S. (2008), Sistem Informasi Akuntansi: Struktur Pengendalian Risiko Pengembangan, Lingga Jaya, Edisi Perdana, pp. 60,22,72. 
JAFTA — Vol. 1 Nomor 2, September (2019)

Dagiliene L and Šutiene K.(2019), “Corporate sustainability accounting information systems: a contingency-based approach", Sustainability Accounting, Management and Policy Journal, ISSN: 2040-8021, Publication date: 31 May 2019

Ward, K.F., Rolland, E. and Patterson, R.A. (2005), "Improving outpatient health care quality: understanding the quality dimensions", Health Care Management Review, Vol. 30 No. 4, pp. 361-71.

Marshall, B.R. and Steinbart, P.J. (2017), Accounting Information Systems, Pearson Education Limited

GSE (2017), “Ghana stock exchange report", available at: www.gse.com.gh/

GSS (2017), "Ghana statistical service report", available at: www.statsghana.gov.gh

Hoque, Z. (2000), “Just-in-time production, automation, cost allocation practices and importance of cost information: an empirical investigation in New Zealandbased manufacturing organizations”, British Accounting Review, Vol. 32 No. 2, pp. 133-59.

Cooper, R. and Kaplan, R.S. (1988), "Measure costs right: make the right decisions", Harvard Business Review, SeptemberOctober, pp. 96-103.

Eloff, M.M. and Solms, V.S.H. (2000), "Information security management: a hierarchical framework for various approaches", Journal of Computers and Security, Vol. 19 No. 3, pp. 243-56.

Doucet, M.S. and Doucet, T.A. (2003), “Control and auditing", Encyclopaedia of Information Systems, Vol. 1, pp. 287-305.

COSO (1994), Internal Control - Integrated Framework, COSO, San Jose, CA.
Colbert, J. and Bowen, P. (1996), “A comparison of internal controls: COBIT, SAC, COSO and SAS 55/78", IS Audit \& Control Journal, Vol. 4, pp. 26-35.

Sugiyono,2008. Metode Penelitian Kuantitatif, Kualitatif dan R\&D. Alfabeta. Bandung 
JAFTA — Vol. 1 Nomor 2, September (2019) 